\title{
LI. Extract form a report made on the 29th of September 1827, on the Probability of finding coal near Leicester
}

\author{
Mr. Francis Forster
}

To cite this article: Mr. Francis Forster (1829) LI. Extract form a report made on the 29th of September 1827, on the Probability of finding coal near Leicester, Philosophical Magazine Series 2, 5:29, 347-350, DOI: 10.1080/14786442908675015

To link to this article: http://dx.doi.org/10.1080/14786442908675015

曲 Published online: 10 Jul 2009.

Submit your article to this journal $[\pi$ 
They are in a cement of minute white quartzy grains. It occupies a low cliff, and is finer at the top than below, and very white. A few yards behind this is another shelf, but it is of very white and fine sandstone.

[To be continued.]

LI. Extract from a Report made on the 29th of September 1827, on the Probability of finding Coal ncar Leicester. By Mr. Francis Fonster, Mineral Surveyor, and Assayer of Coal and Iron Ore.

[With a Map.]

To the Editors of the Philosophical Magazine and Annals. Gentlemen,

IN September 1827, at the request of a person connected with coal and other mines, I made, with the assistance of my brother, Mr. M. Forster, a survey of the country surrounding Leicester, with a view to ascertain the probability of the existence of coal near that town. As circumstances have since occurred, which leave me at liberty to publish this Report, and as the opinions therein contained have also been in a great measure confirmed by the subsequent discovery of a seam of coal by boring near Bagworth (as announced in the New Monthly Magazine for July 1828, and noticed in the Phil. Mag. and Annals for March last), -1 have been induced to offer an extract for publication in your valuable Magazine. Should you do me the favour to insert it, I trust that it may be found to contain hints interesting to the geologist; and I feel confident that they cannot fail to prove so to every one interested in the prosperity of Leicester.

I remain, Gentlemen, your obedient servant, 113, Aldersgate-street, London, Francis Forster. Feb. 26, 1829 .

On examining the strata in the vicinity of Leicester, it was found to consist of new red sandstone or marl, laying in nearly horizontal beds, and so completely covering over and concealing the measures beneath it, that it was found impracticable to trace the basset or outbreak of any of the subjacent strata, until I reached the transition rocks of Charnwood Forest, between which, and the new red sandstone, I was aware that the coal-beds must be found, provided they existed at all. My next step, therefore, was to examine very carefully the junction of the sandstone and transition formations, with a view to ascertain whether any coal-beds, or rocks connected therewith, made their appearance, as underlaying the sandstone, at the precise points where the latter basseted or.crop2 Y 2 
ped out upon the base of the transition hills. Here, however, I was disappointed; for in every part that came under my observation, the sandstone formed a complete junction with the transition rocks, thus effectually preventing any coal-measures which might happen to intervene, from making their appearance on the surface.

Thus circumstanced, it was judged best to abandon all further examination of the strata immediately around Leicester (from which alone the certain existence of coal-measures there could be established), and to commence a survey of the nearest coal-fields already known; and by tracing the direction in which such coal-fields extended, the rocks with which the coal-beds were associated, and their relative position to the transition measures and the new red sandstone, I expected to be able to ascertain the probability of the existence or nonexistence of coal in the immediate neighbourhood of Leicester : for owing to causes already stated, I had given up all hopes of establishing the certainty of its being found there.

From a previous knowledge of that district, I was aware that the Warwickshire coal-field did not extend to Leicester; having seen indications of its final disappearance along its eastern boundary near Nuneaton: my attention was therefore wholly directed to the coal-field extending around Ashby-dela-Zouch, and Cole Orton. I traced the outbreak or disappearance of this coal-field (shaded black in the sketch) in its south-eastern extremity; or in other words, on that side of it lying nearest to Leicester, which outbreak or disappearance is also shown on the accompanying sketch by the line $b, b, b, b$ * extending on the west of Ibstock (a village about twelve miles W. from Leicester) to its junction with the transition rocks at Thrinkston. The transition rocks are shaded purple in the sketch; and their extent to the S.S.W. and S.E. is shown by the dotted line $a, a, a, a$, where they are bounded by the tract of new red sandstone (shaded red) so frequently mentioned. On examining the sketch, it will be observed that the extreme visible extent of the coal-measures towards Leicester is bounded by the red sandstone on the W. of Ibstock, from which place their junction extends in an irregular line to Swannington, beyond which, at Thrinkston, both formations are terminated by a bed of limestone, which appeared to abut against the transition rocks of Charnwood Forest. The line $b, b, b, b$, it is repeated, shows the apparent south-eastern extent of the coal-measures of Ashby-de-

* It will be observed that the line $b, b, b, b$ is broken by the extension of the new red sandstone towards Ashby; the exact limit of which, from want of time, I could not satisfactorily ascertain. 
la-Zouch and Cole Orton: from some unknown cause, however, probably from the intervention of a fault or dyke running from Swannington towards Ibstock, and throwing the strata down to the eastward, the coal-measures are again thrown in, and are found extending under the nerw red sandstone at a pit marked A, near Whitwick, as well as at a pit marked B, near Ibstock: at both of these places, borings have been already made to the coal; and from the similarity of the strata bored through, there is every reason to suppose that the same measures extend from Whitwick to Ibstock, under the new red sandstone, with which the surface is covered to the depth of at least twenty fathoms: the first workable seam of coal bored to at these two places is four feet six inches in thickness; at Ibstock it is about thirty-four, and at Whitwick about fifty fathoms beneath the surface.

Having ascertained the important fact, that the coal-measures, and probably the same coal-measures, extend under the sandstone from Whitwick to Ibstock, a distance of about three miles, and having satisfied myself by observations on the run of these coal strata in general, and of the strata near Whitwick, in particular, that they dip towards the transition strata until they come nearly in contact with them,-I was induced to consider it extremely probable that the coal-measures might still continue to follow the transition rocks, and to form a sort of belt or zone around them, traversing the country in the direction of Bagworth*, Desford, Kirby-Muxloe, and Glenfield, and crossing the Ashby road at the distance of about two miles from Leicester. I was led, therefore, to conclude that a trial for coal might be made with the greatest probability of success in' any part of the dotted line $\mathrm{C}, \mathrm{D}$, in the grounds adjoining Sharman's Lodge. I had arrived at this conclusion, when met at Leicester by the person on whose account the survey was made, with whom it seemed to be a desideratum that a trial for coal should be made near Birstall (See the sketch). I preferred the other situation however, as being more eligib:e for such trial; because, owing to the distance of Birstall from the transition rocks, there appeared that every reason to suppose that the coal-measures would crop-out at or near that place; and consequently any trial for coal there, might probably be made beyond, or at all events too near their basset or outbreak, to afford any beneficial results. On being informed, however, that in cutting a road through a hill near Birstall, a thin bed of coal had been intersected, I immediately proceeded to examine the situation; in doing which, there was found, cer-

* It is near this village that coal has since been discovered. 
tainly not the coal itself, but the outburst of a bed of such argillaceous schist as invariably accompanies coal-beds, mixed with a few small pieces of coal, probably proceeding from the outburst or crop of a seam within a very short distance of the spot. So strong indeed are the indications of coal at this place, that of its existence in the immediate vicinity I have not the slightest doubt. Of its qualities, thickness, \&c., of course no idea can be formed without boring; but there is every reason to'suppose that the same beds will be found here as those which are at present sinking to at Whitwick and Ibstock.

Note.-From the hasty manner in which this survey was made, I had no opportunity of taking elevations; but it is extremely probable that the outbreak of the coal-measures through the new red sandstone near Birstall is conuected with the elevation of the ground. Near Ashby also I observed the like appearance under similar circumstances, where, although the low grounds are occupied by the deposit of new red sandstone, yet on the top of a hill a bed of siliceous sandstone, evidently belonging to the coal-measures, protrudes itself to the surface, and is quarried for the purposes of building.

F.F.

LII. On the Measurement (by Trigonometry) of the Heights of the principal Hills of Wensleydale, Yorkshire. By JонN Nixon, Esq.*

EARLY in June last I commenced the above undertaking, and succeeded, notwithstanding the extremely unfavour: able state of the weather, in completing the requisite measurements by the middle of July. With a view to increase the accuracy of the survey, the third or verification angles of some of the principal triangles were, however, obtained in September, at Ingleborough and Whernside; and in November, at Shunnor Fell : yet so unsatisfactory, in consiequence of the continued haziness of the atmosphere, were the observations, as to render it doubtful whether it would not have been preferable to have rejected them.

In the selection of the hills, the transverse and lateral (or boundary) ridges, of which Wensleydale entirely consists, were surveyed; and the principal passes (or extreme depressions of the ridges) being ascertained, the loftiest point of ground comprehended between every two adjacent passes was carefully determined and marked for measurement. At the head of the dale, several of the transverse ridges, diverging with a gradual descent from one common crest, terminate in lofty and steep head-lands, or knabs. As no part of hills of this description could with propriety be designated the summit, the measurement of the height of any other point was not attempted.

- Communicated by the Author. 


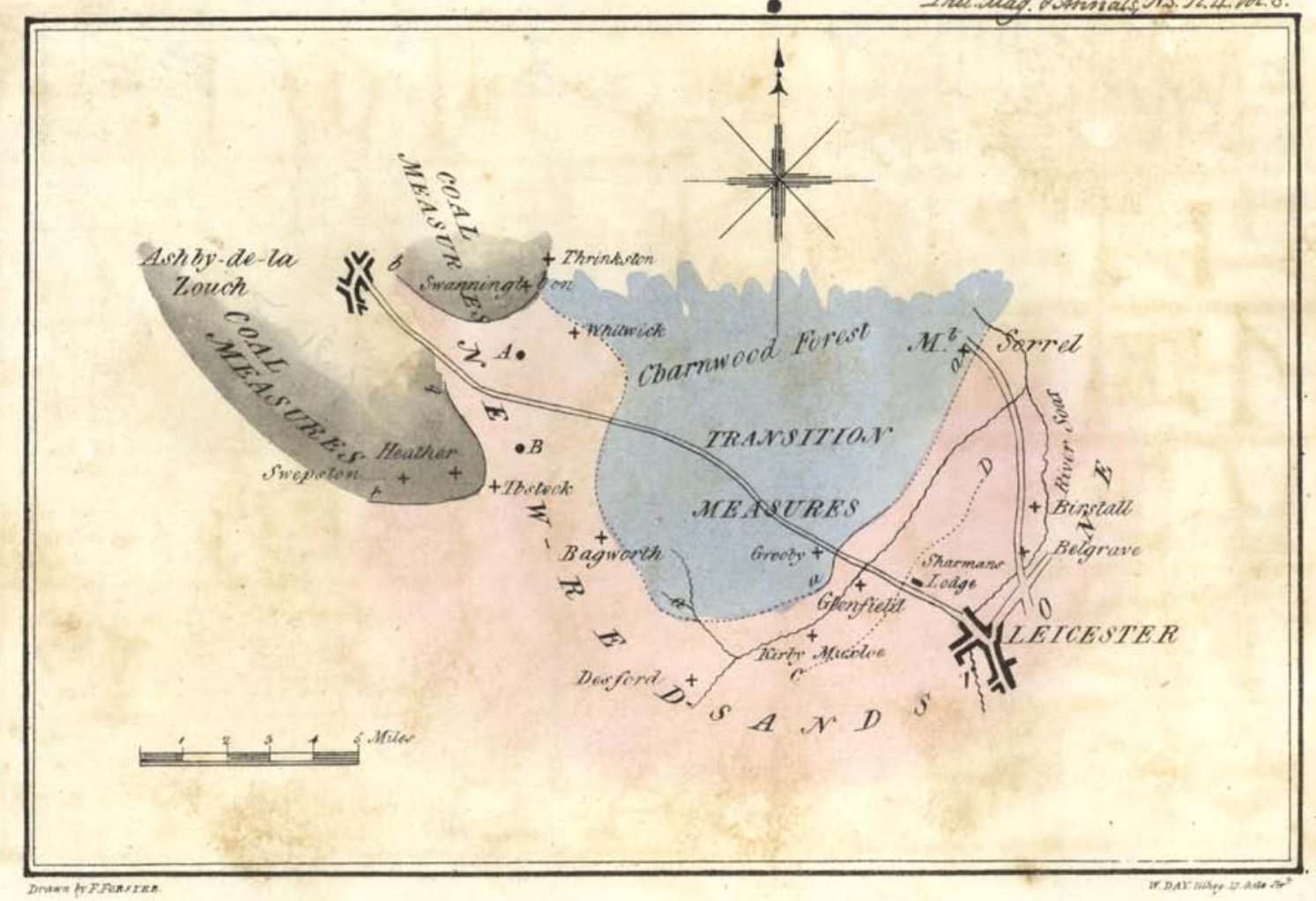

